\title{
Estimating the food requirements of striped bass larvae Morone saxatilis: effects of light, turbidity and turbulence
}

\author{
Edward J. Chesney, Jr \\ Louisiana Universities Marine Consortium, Star Route Box 541 , Chauvin, Louisiana 70344, USA
}

\begin{abstract}
Laboratory experiments were conducted to study the effects of food concentration, turbulence and turbidity on growth and survival of striped bass larvae Morone saxatilis. Initial experiments indicated that striped bass larvae could forage and grow well $\left(G=0.143\right.$ to $\left.0.179 \mathrm{~d}^{-1}\right)$ at food concentrations ranging from 50 to 250 ind $\mathrm{l}^{-1}$ of the copepod Eurytemora affinis and that growth was similar on Artemia sp. and E. affinis. Subsequent experiments tested effects of turbidity $(50,100$, $150 \mathrm{ppm}$ kaolin), reduced light intensity $(2000,1000,600,300$ lux $)$ and turbulence, separately, and then reduced light intensity $(450,70,12,0.4 \mathrm{lux})$ in combination with turbidity $(150 \mathrm{ppm}$ kaolin $)$ and turbulence to determine how these variables moderate food requirements of striped bass larvae. Reducing light or adding turbulence reduced growth and forage rates, while adding turbidity in combination with turbulence apparently ameliorated some of the negative effects of the turbulence. Although growth studies indicated an energetic cost of turbulence, additional experiments comparing weight loss and starvation mortality in turbulent versus non-turbulent conditions showed no significant differences. A comparison of individual growth variability $(G)$ in the turbidity $(150 \mathrm{ppm})$ reduced light treatments and the treatment in total darkness without turbidity or turbulence showed that while average growth rates were positive, a portion of the individuals surviving until $25 \mathrm{~d}$ after hatch were either not growing or losing weight. Low light level in combination with turbidity and turbulence substantially reduced survival and growth rate, but even at very low light levels ( $<1$ lux) and darkness, striped bass were able to survive and grow. Results indicate that previous studies of critical food requirements of striped bass larvae may have overestimated necessary prey levels. Although striped bass larvae are well adapted for growth and survival in highly turbulent, turbid environments, encountering poor feeding conditions in the field is likely to greatly reduce their probability of survival to the juvenile stage.
\end{abstract}

\section{INTRODUCTION}

The striped bass Morone saxatilis is an anadromous fish of considerable commercial and recreational importance, especially within the Chesapeake Bay region (USA) where a large portion of the East Coast stock of striped bass spawns. In recent years stocks of striped bass, as well as other anadromous species spawned in Chesapeake Bay tributaries, have declined. Seining surveys by Maryland Department of Natural Resources for juvenile striped bass indicate that these declines are probably the result of poor survival during the first $60 \mathrm{~d}$ of life (Boone 1980). A number of potential causes for population declines of Chesapeake striped bass have been proposed and studied, including overfishing (Goodyear 1985), dis- ease, pollution (Hall et al. 1985, Westin et al. 1985), acid precipitation, starvation (Martin et al. 1985), predation (MacGovern \& Olney 1988) and habitat loss or alteration (Coutant 1985, Price et al. 1985). Some hypotheses have been tested and discounted as major causes of the declines while others are difficult to test directly. A thorough understanding of how survival and growth are influenced by natural environmental variables (i.e. food resource, temperature, salinity, light) would greatly enhance correlative approaches to understanding mortality patterns of larval stages in the spawning tributaries. Consequently, considerable effort has gone into understanding the basic processes that determine the survival of striped bass larvae.

Several pond and laboratory studies of striped bass larval survival have attempted to define critical food 
levels, identify important foods and to estimate the best temperature-salinity conditions for survival and growth (Meshaw 1969, Doroshev 1970. Turner \& Farley 1971, Otwell \& Merriner 1975, Daniel 1976, Miller 1976, 1978, Lal et al. 1977, Koo \& Johnston 1978, Rogers \& Westin 1979, 1981, Martin \& Malloy 1980, Eldridge et al. 1981, Morgan et al. 1981, Eldridge et al. 1982). In many previous experiments, stocking densities of larvae were high and sizes of experimental tanks small (1 to 91 ), 2 factors that can potentially affect feeding, growth and survival rates (Houde 1975, 1977, Theilacker 1980, Li \& Mathias 1982). Such effects may have led to underestimates of survival rates and growth potential and overestimates of minimum required food concentrations. Furthermore, past studies have made no attempts to evaluate the potential effect of the highly turbulent-turbid conditions encountered by striped bass larvae within their spawning tributaries. Light penetration can be limited to 2 to $3 \mathrm{~m}$ at midday and turbidities are often in the range of 50 to $150 \mathrm{mg} \mathrm{l}^{-1}$ in the spawning tributaries of Chesapeake Bay (Herman et al. 1968, Schubel et al. 1977, Miller 1978).

Despite a large research effort devoted to understanding striped bass larval growth and survival it is still not possible to state explicitly what levels of food are needed for good survival and growth of striped bass larvae in the field, particularly in relation to conditions in Chesapeake Bay spawning tributaries. During the 1984, 1985 and 1986 spawning seasons we studied the effects of food type, turbidity, light and turbulence, on the growth, forage and survival rates of striped bass larvae in the laboratory

\section{MATERIALS AND METHODS}

One-day-old striped bass larvae Morone saxatilis hatched from eggs of Chesapeake and Delaware Canal striped bass adults were used for all the growth experiments. Larvae were held in large (761) well-aerated aquaria at $19{ }^{\circ} \mathrm{C}$ and $3 \%$ salinity until $5 \mathrm{~d}$ after hatching ( $5 \mathrm{DAH})$. On that day, when the larvae first began to feed, they were carefully transferred to experimental aquaria (32l) at the same temperature and salinity as the stock tanks. Each tank was stocked initially at a density of 4 larvae $1^{-1}$, a low enough density to accurately project growth and survival, and not mask effects of the treatment variables. Banks of cool-white fluorescent lights were suspended over each aquaria and maintained on a $12 \mathrm{~h}$ light/12 h dark cycle. The primary food for the growth studies was the estuarine copepod Eurytemora affinis. E affinis is an important component of the zooplankton within spawning areas of striped bass and in the Potomac River was estimated to compose $56 \%$ of the biomass in the diet of striped bass larvae (Setzler-Hamilton et al. 1982). In the laboratory we cultured large stocks of E. affinis (2000 l) at densities up to $3000 \mathrm{l}^{-1}$ for the experiments.

In 1985 and 1986 all treatments were maintained at a food concentration of $100 \mathrm{l}^{-1}$. Eurytemora affinis were stocked to maintain $70 \%$ nauplii and $30 \%$ copepodites and adults which approximates the ratio of their life stages in nature. In 1984, the striped bass larvae were fed copepods until $25 \mathrm{DAH}$. In 1985 and 1986, the larvae were fed copepods until 21 and $19 \mathrm{DAH}$, respectively, and then fed Artemia sp. nauplii on the last 4 to $6 \mathrm{~d}$ of the experiment due to a shortage of copepods.

Automatic feeders were used to maintain food concentrations near nominal levels during the experiments. Each feeder consisted of a reservoir and a solenoid controlled by a timer. Aeration within the reservoir kept the food organisms suspended and evenly distributed. The auto-feeders were set on a $14 \mathrm{~h}$ on $/ 10 \mathrm{~h}$ off cycle beginning $11 / 2 \mathrm{~h}$ before the lighted period and continuing until $1 / 2 \mathrm{~h}$ after the dark period began. Automatic feeding was initiated when the larvae fed at rates where hand feeding could no longer maintain stable food concentrations. Counts of zooplankton in each experimental tank were made severa! times per day to monitor food concentrations and estimate feeding rates.

In 1985, light intensity was reduced by wrapping each aquarium in black plastic and then covering it with a wood frame containing layered plastic screening. By layering the screens illumination was reduced from 2000 to 1000,600 , and 300 lux (ca 20, 11, 6.1 and $3.4 \mu \mathrm{E} \mathrm{m}^{-2} \mathrm{~s}^{-1}$ ). In 1986, light was reduced to $450,70,12$

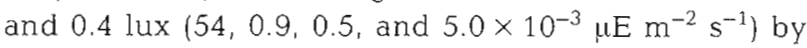
using non-transparent PVC tanks with screened covers so light and turbidity-turbulence could be tested simultaneously. Light was measured as quanta $\left(\mu \mathrm{E} \mathrm{m}^{-2} \mathrm{~s}^{-1}\right)$ with a LiCor $185 \mathrm{~B}$ and converted to photometric units by a conversion factor accounting for the visible spectrum of a fluorescent cool white bulb measured in the PAR waveband (400 to $700 \mathrm{~nm}$ ).

An additional pair of $38 \mathrm{I}$ aquaria were set up in total darkness to test the ability of striped bass larvae to feed and grow without light. The aquaria, covered completely in black plastic, were placed on a rack that was also enclosed in black plastic. These aquaria were maintained in a controlled environmental chamber with the lights off to ensure total darkness. Measurement with the LiCor sensor confirmed that no measurable light in the PAR waveband entered these aquaria.

Kaolin was used to produce turbidities of 50,100 and $150 \mathrm{ppm}(40,90,130 \mathrm{NTU})$. The kaolin was maintained in suspension by turbulent flow generated in specially constructed cylindrical aquaria (Fig. 1). The volume of water entrained by a bubble stream, calculated based on an established relationship between air-flow-rate 


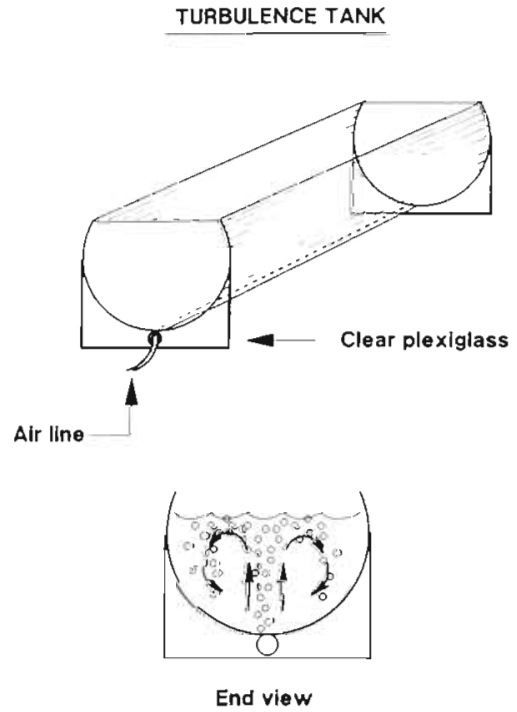

Fig. 1. Turbulence aquaria constructed of PVC and plexiglas. Tanks used in the reduced light treatment were constructed entirely of PVC. Turbulence was generated by air flow from an air line cemented to the bottom of the tank

and water entrainment (Marks \& Shreeve 1968), indicated that water within each tank was completely circulated at least every $7.3 \mathrm{~s}$. The estimated mean velocity within the high turbulence tanks was $6.3 \mathrm{~cm} \mathrm{~s}^{-1}$ with a maximum velocity of ca $10 \mathrm{~cm} \mathrm{~s}^{-1}$. Because the kaolin was grazed by the copepods it was replaced every $4 \mathrm{~d}$ throughout the experiment by allowing it to settle and then siphoning the bottom of the tank. Every second day $50 \%$ of the water in every tank was changed. On water change days the kaolin removed by the water change was replaced with fresh kaolin. The effect of turbulence was tested by having a set of aquaria with turbulent flow but without turbidity.

At $3 \mathrm{~d}$ intervals 5 to 10 individuals were sacrificed and fixed in $5 \%$ formalin for length-weight estimates. All surviving striped bass larvae were preserved at $25 \mathrm{DAH}$. Subsamples of larvae were dried at $60^{\circ} \mathrm{C}$ for 24 to $48 \mathrm{~h}$ depending on size, then reweighed to convert growth to a dry weight basis. Growth was estimated as $G$, the daily instantaneous growth coefficient:

$$
G=\frac{\log \bar{W}_{2}-\log \bar{W}_{1}}{t}
$$

where $\bar{W}_{1}=$ initial weight $(\mathrm{mg}) ; \bar{W}_{2}=$ final weight (mg); $t=$ time interval (d).

The expected number of survivors in each experiment is the number that would have survived had no larvae been sampled and preserved during the course of the experiment. Expected survivorship was estimated from the number of survivors and the numbers preserved following the method outlined in Houde \& Lubbers (1986)
The effect of turbulence on starvation rate was tested by placing 200 larvae in replicate turbulence tanks at $6 \mathrm{DAH}$. At 11 and $16 \mathrm{DAH}$ larvae were carefully removed, counted, 10 individuals sampled to estimate weight losses, and the remaining larvae returned. The experiment was terminated at $21 \mathrm{DAH}$ and all survivors preserved in $5 \%$ formalin. A control stock tank of starved larvae without turbulence was used to compare weight loss rates. Larvae sacrificed for weight loss estimates were dried at $60^{\circ} \mathrm{C}$ for $24 \mathrm{~h}$ and weighed to the nearest $\mu \mathrm{g}$.

Experiments were completed over a 3 yr period with eggs and larvae from the same river system (Chesapeake and Delaware Canal), but from different females in different years which added a potential source of interannual variability in growth and survival. Interannual variability was examined by repeating 1 or 2 treatments from the previous year to compare variability between treatment years.

\section{RESULTS}

Both growth rates and survival rates were high for all treatments in the comparison of food concentration and food type (1984). Growth rates for striped bass larvae ranged from 0.143 to $0.179 \mathrm{~d}^{-1}$ and were highest in the $250 \mathrm{l}^{-1}$ Eurytemora affinis treatment (Table 1). Mortality rates $(Z)$ were low in all the treatments ranging from 0.005 to $0.027 \mathrm{~d}^{-1}$ (Table 1). The $100 \mathrm{l}^{-1}$ E. affinis and the $100 \mathrm{l}^{-1}$ Artemia sp. treatments were not significantly different, although survival rates were higher on Artemia (Student's t-test, $p=0.05$ ). In 1985, turbidity, light intensity, and turbulence all significantly affected the growth of striped bass larvae over the first $25 \mathrm{DAH}$, but none of the factors had a significant affect on survival rate at a food concentration of 100 Eurytemora $\mathrm{I}^{-1}$ (Table 1). Reducing light intensity under non-turbulent conditions significantly affected growth rate (1-way ANOVA, $p=0.05$ ). Larvae grew faster when turbidity was combined with turbulence rather than in turbulence alone at a fixed light intensity (ANOVA, $p=0.05$ ). The amount of turbidity did not significantly affect growth (Scheffe multiple range comparison, $p=$ 0.05). In 1986, instantaneous growth coefficients varied 5-fold, ranging from a low of $0.021 \mathrm{~d}^{-1}$ at the lowest light level (0.4 lux) to a high of $0.103 \mathrm{~d}^{-1}$ in the 450 lux light-turbidity treatment. The results for turbulence without turbidity $(0 \mathrm{ppm})$ were consistent with the 1985 experimental result, indicating that growth and survival in the presence of kaolin turbidity and turbulence is better than in turbulence alone, although the reason for the effect is not clear.

Larvae in total darkness grew surprisingly well with a mean growth coefficient $(G)$ of $0.025 \mathrm{~d}^{-1}$. That treat- 
Table 1. Morone saxatilis. Comparison of 1984, 1985 and 1986 laboratory studies of growth and survival of striped bass larvae. All treatments were cultured at 100 zooplankton $1^{-1}$ in 1985 and 1986 . Estimates are based on conversion to dry weight. Values are means and standard errors of 2 replicates

\begin{tabular}{|c|c|c|c|c|}
\hline Treatment & $\begin{array}{l}\text { Daily instantaneous } \\
\text { growth coefficient }(G)\end{array}$ & $\begin{array}{l}\text { Growth in length } \\
\qquad\left(\mathrm{mm} \mathrm{d}^{-1}\right)\end{array}$ & $\begin{array}{l}\text { Daily instantaneous } \\
\text { mortality coefficient }(Z)\end{array}$ & $\begin{array}{c}\text { Expected percent } \\
\text { survival }\end{array}$ \\
\hline \multicolumn{5}{|l|}{ Food concentration } \\
\hline Eurytemora affinis & & & & \\
\hline $50 \mathrm{l}^{-1}$ & $0.143 \pm 0.001$ & $0.30 \pm 0.01$ & $0.026 \pm 0.005$ & 61.0 \\
\hline $100 \mathrm{l}^{-1}$ & $0.156 \pm 0.004$ & $0.33 \pm 0.02$ & $0.027 \pm 0.005$ & 60.4 \\
\hline $250 \mathrm{I}^{-1}$ & $0.179 \pm 0.003$ & $0.40 \pm 0.01$ & $0.008 \pm 0.005$ & 86.5 \\
\hline $\begin{array}{l}\text { Artemia sp. } \\
100 \mathrm{l}^{-1}\end{array}$ & $0.160 \pm 0.001$ & $0.36 \pm 0.00$ & $0.005 \pm 0.003$ & 91.4 \\
\hline Light only & & & & \\
\hline (2000 lux) & $0.160 \pm 0.002$ & $0.39 \pm 0.01$ & $0.010 \pm 0.005$ & 81.5 \\
\hline$(1000 \operatorname{lux})$ & $0.154 \pm 0.003$ & $0.38 \pm 0.03$ & $0.019 \pm 0.005$ & 69.8 \\
\hline (600 lux) & $0.133 \pm 0.008$ & $0.30 \pm 0.03$ & $0.022 \pm 0.004$ & 66.7 \\
\hline (300 lux) & $0.126 \pm 0.003$ & $0.28 \pm 0.01$ & $0.009 \pm 0.005$ & 85.4 \\
\hline \multicolumn{5}{|l|}{ Turbulence-turbidity } \\
\hline 0 ppm (2000 lux) & $0.090 \pm 0.000$ & $0.21 \pm 0.01$ & $0.029 \pm 0.026$ & 64.2 \\
\hline 50 ppm (450 lux) & $0.121 \pm 0.002$ & $0.28 \pm 0.01$ & $0.005 \pm 0.002$ & 92.1 \\
\hline $100 \mathrm{ppm}(450 \mathrm{lux})$ & $0.127 \pm 0.001$ & $0.29 \pm 0.00$ & $0.007 \pm 0.000$ & 87.7 \\
\hline $150 \mathrm{ppm}(4.50 \operatorname{lux})$ & $0.126 \pm 0.001$ & $0.29 \pm 0.00$ & $0.005 \pm 0.005$ & 91.0 \\
\hline Light-turbidity-turbulence & 19 & & & \\
\hline $450 \mathrm{lux}-150 \mathrm{ppm}$ & $0.103 \pm 0.002$ & $0.20 \pm 0.00$ & $0.024 \pm 0.001$ & 64.2 \\
\hline 70 lux - $150 \mathrm{ppm}$ & $0.081 \pm 0.001$ & $0.18 \pm 0.00$ & $0.022 \pm 0.000$ & 66.4 \\
\hline $12 \mathrm{lux}-150 \mathrm{ppm}$ & $0.053 \pm 0.011$ & $0.10 \pm 0.03$ & $0.030 \pm 0.005$ & 57.1 \\
\hline $0.4 \operatorname{lux}-150 \mathrm{ppm}$ & $0.021 \pm 0.004$ & $0.03 \pm 0.00$ & $0.050 \pm 0.019$ & 43.6 \\
\hline $2000 \operatorname{lux}-0 \mathrm{ppm}$ & $0.039^{a}$ & $0.08^{a}$ & $0.126 \pm 0.035$ & 11.9 \\
\hline Darkness - low turbulence & $0.025 \pm 0.006$ & $0.05 \pm 0.01$ & $0.019 \pm 0.001$ & 69.6 \\
\hline
\end{tabular}

ment also had the highest survival rate in 1986 (Table 1). In general, survival rates were highest for treatments with the highest growth rates (with the exception of the tank held in darkness). Percent survival in 1986 ranged from 11.9 to $69.6 \%$, considerably lower than in the 1984 and 1985 experiments.

Light intensity (lux) significantly affected growth (1-way ANOVA, $p=0.01$ ) of striped bass, especially at low light levels (Table 1 ). Growth varied by more than 5 -fold over the range of light intensities that were tested. A comparison of results of the 1985 and 1986 growth experiments (Table 1; Fig. 2) shows the importance of light on growth. Above intensities of 600 lux, growth was fairly uniform at a given food concentration (Fig. 2). Below 600 lux growth rate declined and below 50 to 100 lux growth declined dramatically, although many striped bass larvae survived, even at the lowest light levels (0.4 lux). Growth in length ranged from $0.03 \mathrm{~mm} \mathrm{~d}^{-1}$ in the low light $(0.4$ lux)-turbidity treatment to $0.39 \mathrm{~mm} \mathrm{~d}^{-1}$ in the full light (2000 lux) without turbulence or turbidity.

Feeding rates were estimated based on daily food rations and the estimated numbers of larvae surviving

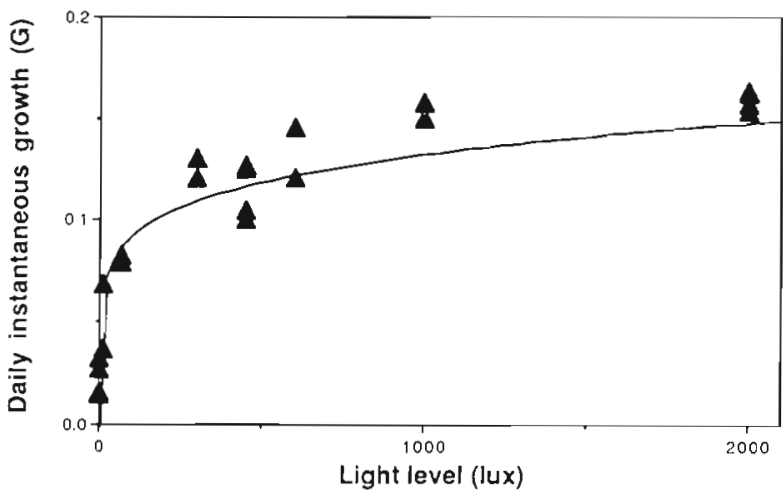

Fig. 2. Morone saxatilis. Daily instantaneous growth coefficients for all light intensities tested during 1985 and 1986 growth experiments with striped bass larvae. A regression of the form $Y=a x^{b}$ was fitted where $a=0.044$ and $b=0.159$

$$
\left(R^{2}=0.82\right)
$$

on a given day. Because Eurytemora affinis were observed to survive for a few days under the experimental conditions it was assumed that all the copepods added to each tank were consumed by the larvae. This assumption, along with the need to estimate the 
number of larvae surviving each day, probably added significantly to the variability observed in the daily feeding rates.

Typical feeding rates observed during the 1984 experiments are depicted in Fig. 3a, b. During the first
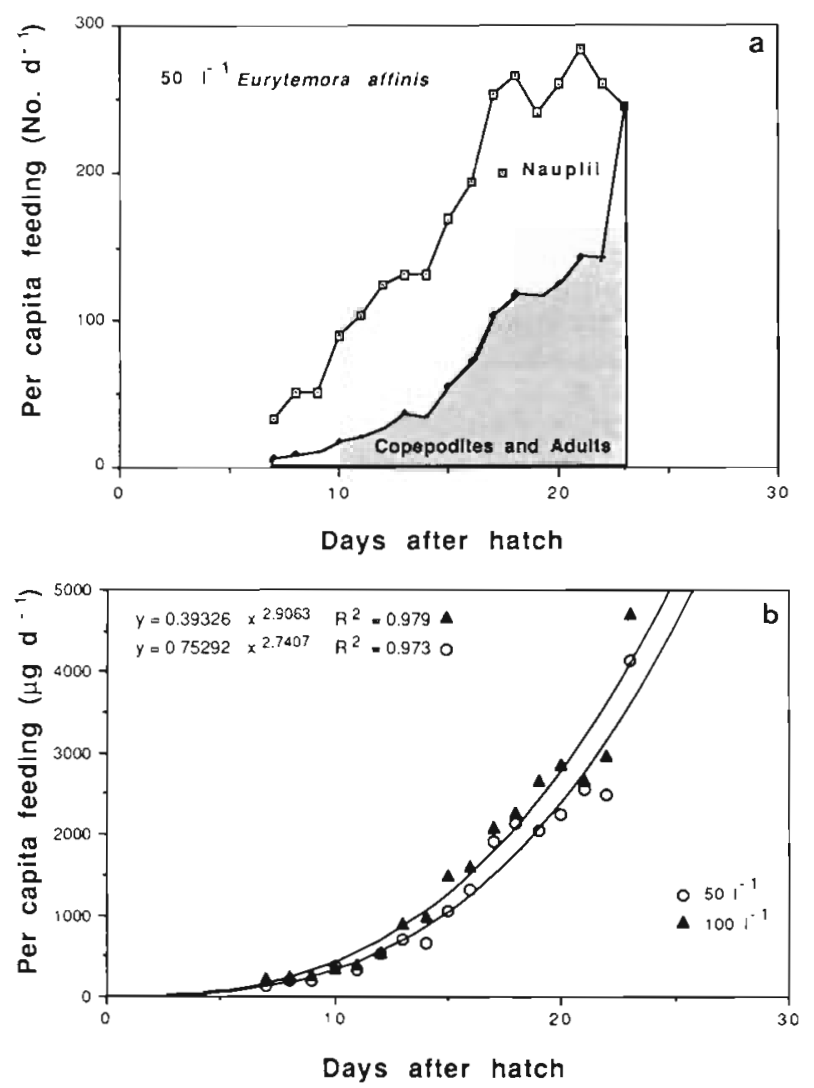

Fig. 3. Morone saxatilis. Daily per capita feeding rates of striped bass larvae fed the copepod Eurytemora affinis at food concentrations of 50 and $1001^{-1}$ (1984). (a) Mean number of food items ingested per day; (b) dry weight estimate of biomass ingested

few days of feeding, striped bass larvae ingested 5 copepod nauplii to every copepodite or adult. For fast growing larvae, ingestion of nauplii ceased between 18 and $21 \mathrm{DAH}$, after which only adults and large copepodites were eaten. In 1985, turbulence and reduced light level tended to reduce per capita ingestion rates with highest ingestion rates in the full light (2000 lux) treatment without turbulence or turbidity (Fig. 4a). Ingestion and growth rate were both generally lower in tanks with high turbulence versus those with low turbulence (Fig. 4a), while turbidity (Fig. 4b) per se seemed to have no predictable effect on per capita ingestion rates over the range of turbidity tested. Feeding rates were not estimated in 1986 because in some of the treatments a significant number of copepods were lost due to natural mortality rather than
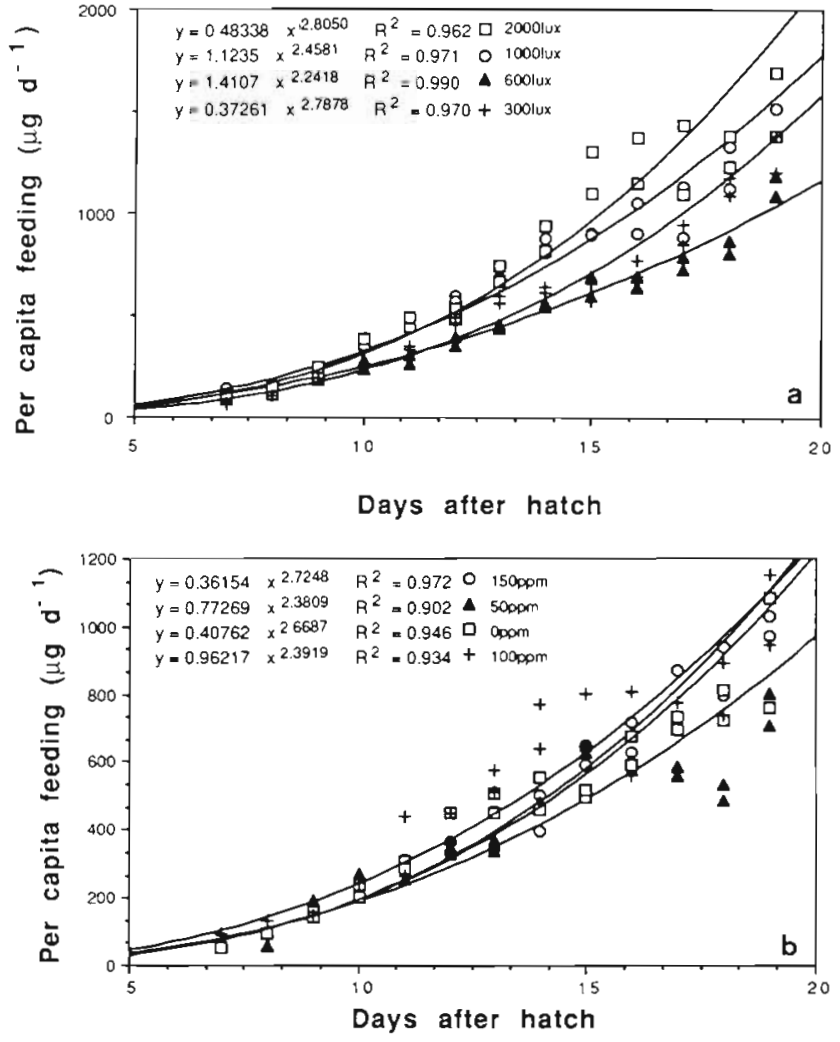

Fig. 4. Morone saxatilis. Daily per capita feeding rates ( $\mu$ g dry wt ind ${ }^{-1} \mathrm{~d}^{-1}$ ) of striped bass larvae fed the copepod Eurytemora affinis under (a) various light $(2000,1000,600,300$ lux) and (b) turbidity $(0,50,100,150 \mathrm{ppm}$ kaolin) conditions at a food concentration of $1001^{-1}$. A regression of the form $Y=a x^{b}$ was fitted to each data set

predation by striped bass larvae and the lower striped bass survival rates in 1986 would have increased the errors associated with estimating survivorship on any given day of the experiment.

The principal goal of the starvation experiment was to test the influence of turbulence on weight loss and thus assess the effect of turbulence on starvation rate. Fig. 5 compares the expected percent survival rates in 2 high turbulence tanks compared to a control with low turbulence. Although mortality rates were somewhat higher in the high turbulence tanks, the overall pattern of starvation losses was not statistically different (Mann-Whitney $U$-test, $p=0.05$ ). A comparison of individual weight losses of starving larvae from these same experiments demonstrated that weight loss rates were similar for larvae starved in a high turbulence and low-turbulence flow field (Fig. 6). The slopes of the regressions are estimates of individual daily dry weight loss rates. They were $4.44 \mu \mathrm{g} \mathrm{d}^{-1}$ in high turbulence and $4.28 \mu \mathrm{g} \mathrm{d}^{-1}$ in low turbulence and were not statistically different (Mann-Whitney $U$-test, $p=0.05$ ).

Fig. 7 a to e shows the frequency distributions of daily 


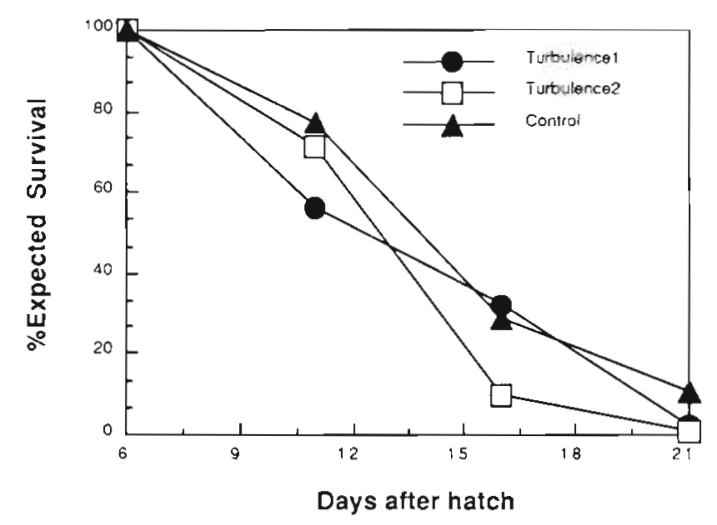

Fig. 5. Morone saxatilis. Expected percent survival of striped bass larvae starved in 2 turbulence tanks compared with a low-turbulence control

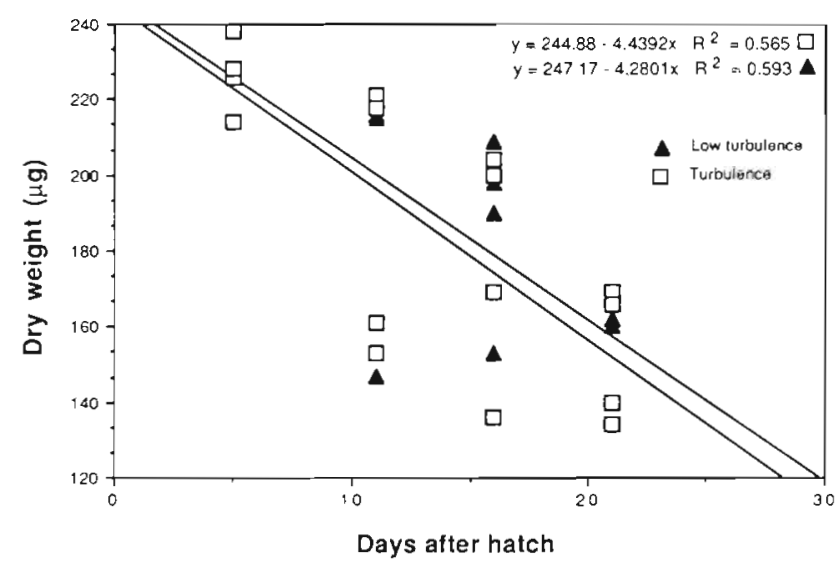

Fig. 6. Morone saxatilis. Regressions of weight loss of striped bass larvae from 6 until $21 \mathrm{~d}$ after hatch in a high turbulence versus a low-turbulence environment

instantaneous growth coefficients (G) for each striped bass larva that survived until the end of the experiment. It is clear that at the lowest light levels (Fig. 7 a to c) and in total darkness (Fig. 7e) that some individuals were not growing while others were growing substantially faster than the mean growth rate. A comparison of individual growth shows that $9.9 \%$ of the survivors in the 0.4 lux treatment (Fig. $7 a$ ), $12.2 \%$ in the 12 lux treatment (Fig. 7b) and $15.6 \%$ in the total darkness treatment (Fig. $7 \mathrm{e}$ ) were losing weight while $87.1 \%$, $33.1 \%$ and $59.3 \%$ of the survivors in the 0.4 lux, 12 lux and darkness treatments, respectively, were growing between 0 and $4.1 \% \mathrm{~d}^{-1}$. At 450 lux all the larvae were growing in excess of $6 \% \mathrm{~d}^{-1}$.

For each of the experimental years either 1 or 2 treatments from the previous year were repeated to serve as a comparison for year to year variations in growth performance of the larvae. Between 1984 and 1985 no differences in growth coefficients was detected between the 2 years, although growth in length was slightly better in 1985 at 100 Eurytemora ${ }^{-1}(t$-test, $p=0.05)$. Between 1985 and 1986 a strong difference in performance was detected (2-way ANOVA, $p=0.001$ ). Growth in weight and in length were both significantly lower in 1986 .

\section{DISCUSSION}

\section{Growth and foraging}

A logical question to ask based on these laboratory results is What is the probability of a striped bass larvae starving in the field and how important is larval nutrition to the recruitment process of striped bass? Several previous studies of growth and nutrition of striped bass larvae have asked this question and suggested that on average there is not enough food in spawning tributaries to support striped bass larval survival unless larvae locate dense patches of food. Comparison of methodologies used in previous studies with the growth studies presented here suggests that previous studies probably overestimated the food requirements of striped bass larvae because they (1) stocked fish at densities too high for optimal growth, (2) used experimental tanks that were too small, (3) did not maintain food concentration constantly at the intended level, and (4) did not account for the complexity of the field conditions a larva is likely to encounter.

Typical densities of those zooplankton commonly eaten by striped bass larvae in Chesapeake tributaries range from 25 to $500 \mathrm{l}^{-1}$ and average 100 to $200 \mathrm{l}^{-1}$ (Beaven \& Mihursky 1979, Setzler-Hamilton et al. 1982). Miller (1976) estimated that a food concentration of 1864 Artemia $1^{-1}$ would be required to meet the minimum daily ration of first-feeding striped bass larvae. Eldridge et al. (1982) estimated the food requirements to be an order of magnitude higher than the abundance of food organisms in nature. Both groups of investigators speculated that such high requirements might be met in nature by encountering dense patches of food. Density gradients and patchiness exist in plankton communities and zooplankters, including fish larvae, concentrate along frontal areas or other physical features within estuaries. However, evidence presented here indicates that striped bass larvae are capable of significant ingestion, growth and survival when food levels are near the mean ambient levels found in Chesapeake Bay tributaries. Encountering dense patches of food is obviously not the entire explanation for the survival and growth patterns of striped bass larvae observed in the field. Dense patches of food will convey a greater opportunity for feeding success. However, striped bass larvae can forage and grow effectively on relatively low food concentrations and under extremes of light, turbidity and turbulence. 

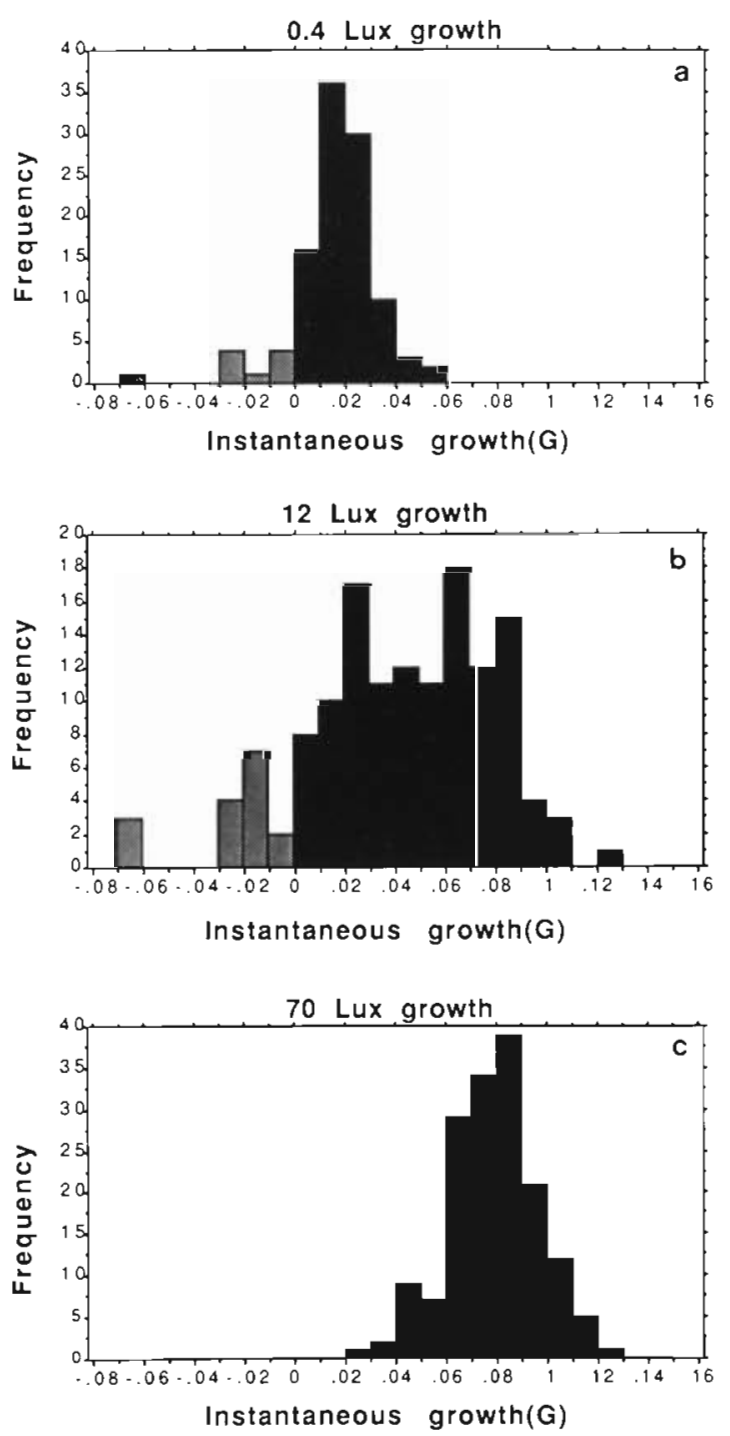

Feeding rates reported here for first feeding yolk-sac larvae of 40 to $80 \mathrm{mg}$ dry wt d $\mathrm{d}^{-1}$ or 45 nauplii and 6 or 7 copepodites and adult copepods fall within the range reported previously for both laboratory and field caught larvae (Miller 1978, Eldridge et al. 1982). The results indicate that good growth and survival are possible in the laboratory at food concentrations normally found in Chesapeake tributaries. Houde \& Lubbers (1986) had previously cultured striped bass larvae at 100 Artemia $^{-1}$ with high growth and survival rates. Results reported here show that good growth and survival are also possible on one of their natural prey items, even when adverse factors such as turbidity, turbulence and low light are considered.

Differences between my results and those previously reported may in part be due to the lower inherent food value of some strains of Artemia spp. (Watanabe et al. 1983). In my experiments, growth was equally good
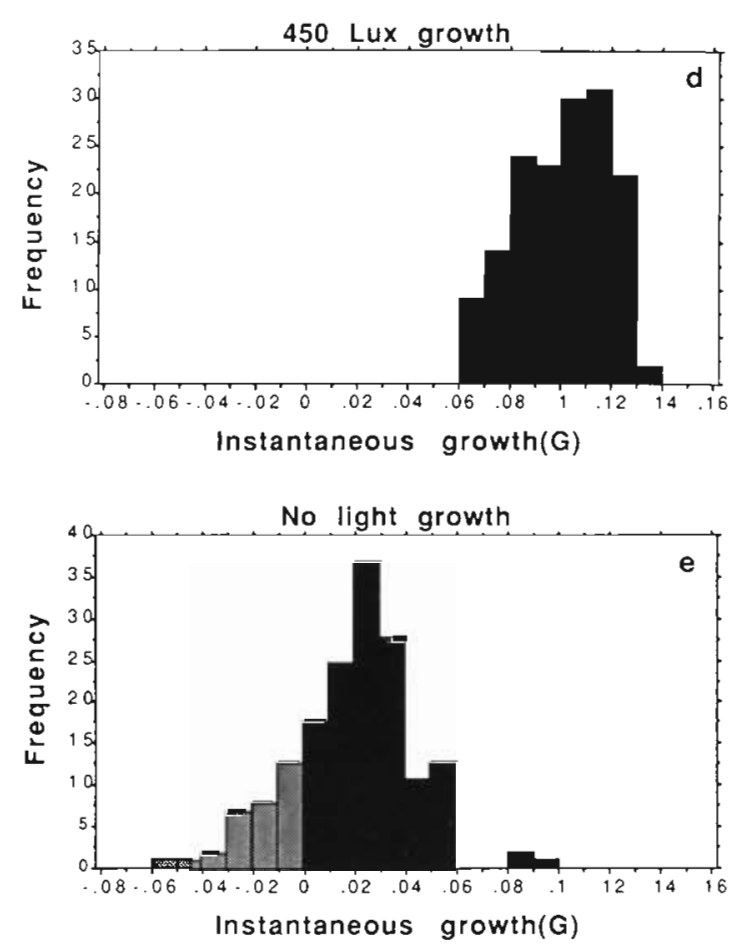

Fig. 7. Morone saxatilis. Frequency of individual daily instantaneous growth coefficients $(G)$ of striped bass larvae grown at (a to e respectively) $0.4,12,70$ and 450 lux with turbulence and turbidity and in total darkness without turbulence or turbidity. Shading contrasts positive and negative growth

and survival was higher on Artemia nauplii than on their natural prey Eurytemora affinis. The high survival rates of striped bass larvae fed Artemia (Table 1) was probably related not to quality, but to ease of capture of these prey by first-feeding larvae. When feeding on Artemia, striped bass larvae typically 'gulp' their prey, but they switch to an S-start when attacking copepod nauplii and adults (pers. obs.). The variability in attack success inherent in different prey types may be an important factor to consider in the future if laboratory estimates of feeding rate are to be applied to understanding food requirements of larval fish in the field.

\section{Light, turbulence, turbidity}

Fish larvae are generally considered to be predominantly sight feeders (Hunter 1981). Several inves- 
tigators have reported that reducing light level reduces forage efficiency of fish larvae (Blaxter 1966, 1986, Hunter 1968, Kiyono \& Hirano 1981). Thus, reducing light levels sufficiently would be expected to reduce growth and forage rates as was observed (Table 1; Fig. $3)$. There is evidence in the literature to suggest that striped bass larvae can feed in very low light or no light (McHugh \& Heidinger 1977) - a result confirmed in the present study. The mechanism for feeding in the dark is not clear. Herring juveniles Clupea harengus swim faster and adopt a filter feeding strategy when forced to feed in the dark on Artemia nauplii (Batty et al. 1986). Although filter feeding cannot be ruled out it seems unlikely that a first feeding striped bass larva would be able to filter an active prey, such as copepods, at such low food densities. Hence, a mechano- or chemosensory strategy seems most likely for striped bass larvae.

The mortality pattern and the weight loss rates observed in the starvation experiments agreed well with patterns observed in previous starvation experiments with striped bass larvae. For example, Rogers \& Westin (1981) found that striped bass larvae starved to death in $29 \mathrm{~d}$ at $18^{\circ} \mathrm{C}$ and $21 \mathrm{~d}$ at $21^{\circ} \mathrm{C}$. Eldridge et al. (1981) observed complete starvation of a laboratory population of striped bass larvae in $29 \mathrm{~d}$ at $18^{\circ} \mathrm{C}$. A comparison of my growth and starvation data with previous studies suggests that while turbulence may add a minor energetic cost via swimming to a growing and foraging larva, the metabolic cost of temperature is likely to be the most important environmental factor likely to affect weight loss in a first-feeding striped bass larvae (Rogers \& Westin 1981).

Observed effects of turbidity on striped bass larvae were not as expected based on previous studies of fish foraging in turbid environments. Intuitively, turbidity should reduce the prey field of a predator by reducing light and visibility and thus the number of successful encounters. Narrowing of the prey field by turbidity has been reported for bluegill Lepomis macrochirus (Vinyard \& O'Brien 1976) and flounder Platichthys flesus (Moore \& Moore 1976). Swenson \& Matson (1976) reported no reduction in feeding rate by larval lake herring Coregonus artedii at moderate turbidities (28 ppm), but they did note that larvae aggregated closer to the surface in turbid water. Boehlert \& Morgan (1985) studied larval Pacific herring Clupea harengus pallasi and found enhancement of feeding at moderate to high turbidities (500 to $1000 \mathrm{ppm}$ ). They attributed this result to increased prey contrast and noted that larvae may have been distributed close to the surface in their experimental tanks, perhaps in response to low light. Mathews (1984) reported a similar pattern for distribution of shad larvae Dorosoma spp. in response to high turbidity in Lake Texoma (Oaklahoma, USA). He speculated that concentration of shad larvae in the surface layer may have been a response to low light caused by the high turbidity. A similar response may have caused enhancement of feeding in the experiments with Pacific herring, especially if food organisms were redistributed close to the surface in response to light level.

Narrowing of the prey field by turbidity and its effect on foraging ability may be a matter of scale of perception rather than differences in visual acuity. The effect would be greatest for juvenile and adult fish which perceive and attack prey at relatively great distances compared to larvae. For example, planktivorous fish foraging in a prey field of 100 prey $^{-1}$ will be within 1 to $2 \mathrm{~cm}$ of a food particle at all times if the food is randomly distributed (Gallagher \& Burdick 1970). Reported prey fields for larvae typically range from $1 \mathrm{~mm}$ to centimeters (Rosenthal \& Hempel 1970, Blaxter \& Staines 1971, Hunter 1972). Reaction distances for juvenile and adult planktivorous fishes such as bluegill, white crappie, grayling, and brook trout range from 8 to $30 \mathrm{~cm}$ depending on the species, ambient light and turbidity ( $O$ 'Brien 1987). If turbidity were to limit prey visibility such that zooplankton prey were only visible at a few centimeters, it would have little effect on a larval fish (as long as light were sufficient) whereas the effect on the perception of prey by juveniles would be dramatic. Turbidity per se would in theory have little effect on feeding of larvae except as it influences light attenuation, while light intensity should have a strong influence on foraging by larval, juvenile and adult fishes.

The turbidity and light results support the conclusion that the major effect of turbidity on striped bass larvae may be to reduce the light levels needed to feed effectively, rather than reducing forage rates by reducing the prey field. The size and the shape of the prey field will be substantially different in turbulent than in still waters regardless of turbidity level. The effectiveness of a predator under those conditions will depend on its ability to maneuver and adapt its attack strategy in the turbulent-turbid conditions. It appears that Mansueti (1961) was correct when he suggested that striped bass larvae are well adapted to the highly turbid-turbulent conditions of the Chesapeake Bay tributaries.

\section{Individual growth variability}

Treatment means provide a good representation of the average effects of the treatment variables, while variation about those means potentially provides the greatest insight into the probability of an individual larva's success or failure. It is important to look at individual growth variability in these experiments because the duration of the experiment was until $25 \mathrm{DAH}$ and striped bass larvae can survive in a totally starved condition for 20 to 30 d (Rogers \& Westin 1979, 
Eldridge et al. 1981). While final survivorships in a 25 DAH experiment may not adequately reflect chances for long-term survival, short-term experiments are advantageous in that the range of individual growth patterns of survivors under a given set of environmental conditions can be compared and predictions made about each individuals relative probability of survival.

Environmental variability is presumably small in the laboratory compared to the field, especially for a given replicate within a treatment. Thus, the observed variability is a combination of individual growth variability and variability between replicates. Histograms of individual growth variability showed that growth rates of individuals can be quite variable, even when experiments are designed to minimize variability (Fig. 7).

When variability in food concentration is combined with other sources of environmental variability that affect feeding and growth (light, turbidity, temperature), then it becomes clear that food, through its influence on growth, plays a major role in the probability of survival for a given striped bass larva. In the present experiments some physical variables were tested at a single food concentration of 100 organisms $1^{-1}$. Some larvae survived and grew under all conditions tested; however, we did not test extremes of food concentration in combination with low light and turbidity. In the field, concentrations of food organisms typically range from 100 to 200 zooplankton $\mathrm{l}^{-1}$ but are temporally and spatially variable, potentially ranging down to 5 to 10 zooplankters $\mathrm{I}^{-1}$ (Heinle et al. 1979). Predators on fish larvae are also a factor potentially interacting with growth rate to limit the number of larvae reaching the juvenile stage, especially when the larvae are susceptible to stage or size specific predation effects (Houde $1986,1987)$. The temporal and spatial variability of food organisms, extremes of physical conditions, individual growth variability, as well as losses to predators can all interact to determine the success of a given year class.

Acknowledgements. I thank the Maryland Sea Grant office and the Maryland Department of Natural Resources for their financial support of this work. Special thanks to Larry Lubbers, Colleen Zastrow, Sarah Houde and Tim Newberger for their assistance with this study during spawning season, also to Skip Bason, Md. DNR for eggs and larvae, and to Colin Marks for technical advice. I thank Ed Houde for reviewing a draft of the manuscript and Ms Gail Canaday who kindly typed the manuscript.

\section{LITERATURE CITED}

Batty, R. S., Blaxter, J. H. S., Libby, D. A. (1986). Herring (Clupea harengus) filter feeding in the dark. Mar. Biol. 91: 371-375

Beaven, M., Mihursky, J. A. (1979). Analysis of striped bass larval stomachs. 1976 Potomac estuary collections final report. Submitted to Maryland Power Plant Siting Pro- gram. UMCEES Ref. No. 79.45 CBL, Chesapeake Biological Laboratory, Solomons, Md., USA

Blaxter, J. H. S. (1966). The effect of light intensity on the feeding ecology of herring. In: Bainbridge, R., et al. [eds.] Light as an ecological factor Brit. Ecol. Soc. Symp. no. 6. Blackwell Scientific Publications, Oxford, p. 393-409

Blaxter, J. H. S. (1986). Development of sense organs and behaviour of teleost larvae with special reference to feeding and predator avoidance. Trans. Am. Fish. Soc. 115: 98-114

Blaxter, J. H. S., Staines, M. E. (1971). Food searching potential in marine fish larvae. In: Crisp. D. J. [ed.] Proc. 4th European Marine Biology Symposium. Cambridge Univ. Press, Cambridge, p. 467-485

Boehlert, G. W., Morgan, J. B. (1985). Turbidity enhances feeding abilities of larval Pacific herring, Clupea harengus pallasi. Hydrobiologia 123: 161-170

Boone, J. G. (1980). Estuarine fish recruitment survey. July 1, 1979 through June 30, 1980. Maryland Department of Natural Resources, Annapolis, Md., USA

Coutant, C. C. (1985). Striped bass temperature and dissolved oxygen: a speculative hypothesis for environmental risk. Trans. Am. Fish. Soc. 114: 31-61

Daniel, D. A. (1976). A laboratory study to define the relationship between survival of young striped bass (Morone saxatilis) and their food supply. Calif. Dept Fish Game, Anadromous Fish. Branch, Admin. Rep. 76-1, p. 1-13

Doroshev, S. 1. (1970). Biological features of the eggs, larvae and young of the striped bass (Roccus saxatilis Walbaum) in connection with the problem of its acclimatization in the USSR. J. Ichthyol. 10: 235-248

Eldridge, M. B., Whipple, J. A., Bowers, M. J. (1982). Bioenergetics and growth of striped bass, Morone saxatilis embryos and larvae. Fish. Bull. U.S. 80: 461-474

Eldridge, M. B., Whipple, J. A., Eng, D., Bowers, M. J., Jarvis, B. M. (1981). Effects of food and feeding factors on laboratoryreared striped bass larvae. Trans. Am. Fish. Soc. 110: $111-120$

Gallagher, B. S., Burdick, J. E. (1970). Mean separation of organisms in three dimensions. Ecology 51: 538-540

Goodyear, C. P. (1985). Toxic materials fishing and environmental variation: simulated effects on striped bass population trends. Trans. Am. Fish. Soc. 114: 107-113

Hall, L. W. Jr, Pinkney, A. E., Horseman, L. O., Finger, S. E. (1985). Mortality of striped bass larvae in relation to contaminants and water quality in a Chesapeake Bay tributary. Trans. Am. Fish. Soc. 114: 861-868

Heinle, D. R., Pulles, P., Millsops, H. S. (1979). Population dynamics of zooplankton in upper Potomac estuary March through May, 1977. Final report to the State of Maryland, Power Plant Siting Program. University of Maryland, Chesapeake Biological Laboratory, UMCEES 79-82-CBL. Solomons, Maryland

Herman, S. S., Mihursky, J. A., McErlean, A. J. (1968). Zooplankton and environmental characteristics of the Patuxent River estuary 1963-1965. Chesapeake Sci. 9: 67-82

Houde, E. D. (1975). Effects of stocking density and food density on survival, growth and yield of laboratory-reared larvae of sea bream Archosargus rhomboidalis (L.) (Sparidae). J. Fish Biol. 7: 115-127

Houde, E. D. (1977). Food concentration and stocking density effects on survival and growth of laboratory-reared larvae of bay anchovy Anchoa mitchilli and lined sole Achirus lineatus. Mar. Biol. 43: 333-341

Houde, E. D. (1986). Potential for growth, duration of early life stages and regulation of recruitment in marine fish. Coun. Meet. Int. Coun. Explor. Sea C.M.-ICES/L:28, p. 1-11

Houde, E. D. (1987). Fish early life history dynamics and 
recruitment variability. Trans. Am. Fish. Soc. Symp. 2 $17-29$

Houde, E. D., Lubbers, L. (1986). Survival and growth of striped bass Morone saxatilis and Morone hybrid larvae laboratory and pond enclosure experiments. Fish. Bull U.S. 84: 905-914

Hunter, J. R. (1968). Effects of light on schooling and feeding of jack mackerel, Trachurus symmetricus. J. Fish. Res. Bd Can. 25: 393-407

Hunter, J. R. (1972). Swimming and feeding behavior of larval anchovy, Engraulis mordax. Fish. Bull. U.S. 74: 81-88

Hunter, J. R. (1981). Feeding ecology and predation of marine fish larvae. In: Lasker, R. (ed.) Marine fish larvae. Univ. Washington Press, Seattle, p. 33-77

Kiyono, M., Hirano, R. (1981). Effects of light on the feeding and growth of black porgy, Mylio macrocephalus (Basilewsky), postlarvae and juveniles. In: Lasker, R, Sherman, K. (eds.) The early life history of fish: recent studies. Rapp. P.-v. Réun. Cons. int. Explor. Mer 178: 334-336

Koo, T. S. Y., Johnston, M. L. (1978). Larvae deformity in striped bass, Morone saxatilis (Walbaum), and blueback herring Alosa aestivalis (Mitchell), due to heat shock treatment of developing eggs. Environ. Pollut. 16: 137-149

Lal, K., Lasker, R., Kuljis, A. (1977). Acclimation and rearing of striped bass larvae in sea water. Calif. Fish Game 63 $210-218$

Li, S., Mathias, J. A. (1982). Causes of high mortality among cultured larval walleyes. Trans. Am. Fish. Soc. 111: 710-721

MacGovern, J. C., Olney, J. E. (1988). Potential predation by fish and invertebrates on early life history stages of striped bass in the Pamunkey River, Virginia. Trans. Am. Fish. Soc. 117 152-161

Mansueti, R. J. (1961). Effects of civilization on striped bass and other estuarine biota in Chesapeake Bay and tributaries. In: Higman, J. B. (ed.) Proc. Gulf and Caribbean Fisheries Institute, Univ. of Miami, Florida, p. 110-136

Marks, C. H., Shreeve, C. A. Jr (1968). An investigation of entrainment of water by a stream of successive bubbles. Proc. Am. Soc. Mechanical Engineers, winter meeting, ASME, N.Y

Martin, F. D., Malloy, R. (1980). Histological and morphometric criteria for assessing nutritional state of larval striped bass, Morone saxatilis. In: Fuiman, L. (ed.) Proc. 4th Ann. Larval Fish Conf., U.S. Fish and Wildlife Service Biological Services Program, Wash., D.C. FWS/OBS-80/43, 4: 157-166

Martin, F. D., Wright, D. A., Means, J. C., Setzler-Hamilton, E. M. (1985). Importance of food supply to nutritional state of larval striped bass in the Potomac River estuary. Trans. Am. Fish. Soc. 114: 137-145

Mathews, W J. (1984). Influence of turbid inflows on the vertical distribution of larval shad and freshwater drum. Trans. Am. Fish. Soc. 113: 192-198

McHugh, J. J., Heidinger, R. C. (1977). Effects of light on feeding and egestion time of striped bass fry. Prog. Fish Cult. 39: 33-34

Meshaw, J. C. Jr (1969). A study of feeding selectivity of striped bass fry and fingerlings in relation to zooplankton availability. Master's thesis, N. Carolina State Univ.

Miller, P. E. (1976). Experimental study and modelling of striped bass egg and larval mortality. Doctoral diss., The Johns Hopkins University

Miller, P. E. (1978). Food habit study of striped bass post yolksac larvae. Special Report 68. Chesapeake Bay Institute, The Johns Hopkins University. Submitted to Power Plant

This article was presented by Professor K. R. Tenore,

Solomons, Maryland, USA
Siting Program, Maryland Department of Natural Resources

Moore, J. W.; Moore, I. A. (1976). The basis of food selection in flounders, Platichthys flesus (L.), in the Severn Estuary. J Fish Biol. 9: 139-156

Morgan, R. P., II, Rasin, V. J. Jr, Copp, R. L. (1981). Temperature and salinity effects on development of striped bass eggs and larvae. Trans. Am. Fish. Soc. 110: 95-99

O'Brien, W. J. (1987). Planktivory by freshwater fish. thrust and parry in the pelagia. In: Kerfoot, W C., Sih, A. (eds.) Predation: direct and indirect impacts on aquatic communities. Univ. Press of New England, Hanover, p. 3-16

Otwell, W. S., Merriner, J. V (1975). Survival and growth of juvenile striped bass, Morone saxatilis, in a factorial experiment with temperature, salinity and age. Trans. Am. Fish. Soc. 104: 560-566

Price, K. S., Flemer, D. A., Taft, J. L., Mackiernan, G. B., Nehlsen, W., Biggs, R. B., Burger, N. H., Blaylock, D. A. (1985). Nutrient enrichment of Chesapeake Bay and its impact on the habitat of striped bass: a speculative hypothesis. Trans. Am. Fish. Soc. 114: 97-106

Rogers, B. A., Westin, D. T (1979). The combined effect of temperature and delayed intitial feeding of the survival and growth of larval striped bass Morone saxatilis (Walbaum). In: Jacoff, F. S. (ed.) Advances in marine environmental research. U.S. Environmental Protection Agency, Rep. EPA-600/9-79-035, p. 234-250

Rogers, B. A., Westin, D. T. (1981). Laboratory studies on effects of temperature and delayed initial feeding on development of striped bass larvae. Trans. Am. Fish. Soc. 110: $100-110$

Rosenthal, H., Hempel, G. (1970). Experimental studies in feeding and food requirements of herring larvae (Clupea harengus L.). In: Steele, J. H. S. (ed.) Marine food chains. Univ. Calif. Press, Berkeley, p. 344-364

Schubel, J. R., Williams, A. D., Wise, W. M. (1977). Suspended sediment in the Chesapeake and Delaware Canal. Spec. Rept. No. 11, Marine Science Research Center, SUNY, Stony Brook, NY, p. 1-72

Setzler-Hamilton, E. M., Jones, P. W., Drewry, G. E., Martin, F. D., Ripple, K. L., Beaven, M., Mihursky, J. A. (1982). A comparison of larval feeding habits among striped bass, white perch and clupeidae in the Potomac estuary. Tech. Rep. Maryland Power Plant Siting Program, submitted to Maryland Dept. Nat. Res., p. 1-127

Swenson, W. A., Matson, M. L. (1976). Influence of turbidity on survival, growth and distribution of larval lake herring (Coregonus artedii). Trans. Am. Fish. Soc. 4: 541-545

Theilacker, G. H. (1980). Rearing container size affects morphology and nutritional condition of larval jack mackerel, Trachurus symmetricus. Fish. Bull. U.S. 78: 789-791

Turner, J. L. Farley, T C. (1971). Effects of temperature, salinity and dissolved oxygen on the survival of striped bass eggs and larvae. Calif. Fish Game 57: 268-273

Vinyard, G. L., O'Brien, W J. (1976). Effects of light and turbidity on the reactive distance of bluegill (Lepomis macrochirus). J. Fish. Res. Bd Can. 33: 2845-2849

Watanabe, T., Kitajima, C., Fujita, S. (1983). Nutritional values of live organisms used in Japan for mass propagation of fish: a review. Aquaculture 34: 115-143

Westin, D. T., Olney, C. E., Rogers, B. A. (1985). Effects of parental and dietary organochlorines on survival and body burdens of striped bass larvae. Trans. Am. Fish. Soc. 114 $125-136$

Manuscript first received: April 5, 1988

Revised version accepted: January 31, 1989 